\title{
Réz és ausztenites korrózióálló acél vegyes kötésének kialakítása ultrahangos hegesztéssel
}

\section{Producing a Dissimilar Joint of Copper to Austenitic Stainless Steel by Ultrasonic Welding}

\author{
Schramkó Márton, ${ }^{1}$ Kovács Tünde Anna ${ }^{2}$ \\ 1,2 Óbudai Egyetem, Bánki Donát Gépész és Biztonságtechnikai Mérnöki Kar, Anyag és alakítástechnológiai \\ Intézeti Tanszék, Budapest, Magyarország, kovacs.tunde@uni-obuda.hu
}

\begin{abstract}
There are several possibilities for establishing a cohesion joint between dissimilar metals. In the case of thin sheets, the ultrasonic welding process is suitable. This process can establish a cohesion joint rapidly, with a low heat input between the thin sheets. The authors have tried to determine the optimal ultrasonic welding parameters for copper and austenite stainless steel joining by using an experimental method of joining. Suitable results were obtained by welding tests due dissimilarities in the chemical, physical and mechanical properties of the copper and stainless steel. A standard size sheet thickness and test sample was used for the welding by different parameters. The parameters were refined based on the theoretical and practical knowledge during the experiments. The experimental welding was made by a Branson L20 type welder machine. The joint made by the different parameters was inspected by shearing-tensile tests (maximal force level).
\end{abstract}

Keywords: ultrasonic welding, copper, stainless steel.

\section{Összefoglalás}

Különböző fémek között kohéziós kötés létrehozására számos lehetőség van. Vékony lemezek esetében jól alkalmazható hegesztési eljárás az ultrahangos hegesztés. Ezzel az eljárással gyorsan, kis hőbevitellel lehet kohéziós kötést létesíteni vékony lemezek között. A szerzők ebben a munkában tiszta réz és ausztenites korrózióálló acéllemezek ultrahangos hegesztésének optimális paramétereit igyekeztek meghatározni kísérleti úton. A réz és az ausztenites acél eltérő kémiai, fizikai és mechanikai tulajdonságai miatt a próbahegesztés hozott eredményt. A kísérletekhez a szerzők adott lemezvastagságú és méretű próbatesteket használtak fel, majd ezen paraméterek változtatása mellett hegesztették össze. Az előzetes elméleti és gyakorlati tapasztalatok alapján megválasztott paraméterek finomítását végezték el a kísérletsorozat során. A kísérleti hegesztésekhez Branson L20 típusú ultrahangos hegesztőberendezést alkalmaztak. A különböző paraméterekkel készült kötéseket húzó-nyíró vizsgálattal minősítették, a maximális erő értékével.

Kulcsszavak: ultrahangos hegesztés, réz, korrózióálló acél.

\section{Bevezetés}

Az ipar a kötéstechnológiát egyre újabb kihívások elé állítja. A kis hőbevitelű eljárások nem csak az ömlesztőhegesztés területén fejlődnek, de egyre szélesebb körben alkalmaznak sajtolóhegesztési eljárásokat vagy forrasztást a vékony lemezek összekapcsolására [1, 2]. Az ultrahangos hegesztés kis hőbevitelt okozó, hidegsajtoló hegesztési eljárás, mellyel kohéziós kötést hoznak létre hozzáadott hegesztőanyag alkalmazása nélkül. Az eljárás igen egyszerü, amennyiben a hegesztési paraméterek optimalizálása megtörtént, a kezelő személynek nem kell minősített hegesztőnek lennie, betanított munkás által elvégezhető feladat, ráadásul a jellemző hegesztési veszélyfor- 
rások (fröcskölés, füst, hő) is igen csekély mértékben jelentkeznek. Természetesen az ultrahanghatás ellen a kezelő hallószerveit védeni szükséges.

Az ultrahangos hegesztés kezdetei visszanyúlnak Pierre Curie-hez, aki fizika- és kémiaprofeszszor volt, a kristályos anyagok vizsgálata során, 1881-ben felfedezte az elektromos feszültség és a nyomás kapcsolatát [3]. A párizsi Sorbonne Egyetem fizikalaboratóriumában látott el asszisztensi feladatokat már fiatalkori éveiben is. Doktoranduszi éveit a krisztallográfiának szentelte, ezen belül a kristályos anyagok eloszlásának problémájával foglalkozott, amelyeket a szimmetria törvényszerüsége alapján vizsgált. A doktori kinevezést 1895-ben kapta. Bátyjával, Jaque Curievel együtt alátámasztották a piezoelektromosság létét, és a megnevezés is tőlük származik. Ez a felfedezés volt az alapköve a modern ultrahangos energiaátalakítóknak és az ultrahangos hegesztés kialakulásának, majd egyre szélesebb körű elterjedésének [3].

George Ludwig, a Pennsylvania Egyetem kutatója 1940-ben vizsgálta, majd rögzítette a hanghullámok irányváltozását a test különböző részein keresztül. Az emberi szervezetben létrejövő epekő kimutatásával és roncsolásmentes vizsgálatával töltötte a legtöbb időt a kutatásai közül. Sikeres eredményei nyomán megszülethetett az ultrahangos vizsgálat, amit a mai napig rengeteg helyen alkalmaznak az orvostudomány területén. Ennek elve megegyezik az iparban alkalmazott roncsolásmentes anyagvizsgálatokéval, az eljárást leginkább a hegesztett kötések ellenőrzésénél használjuk a gyakorlatban.

1960-ban az eljárás elkezdett elterjedni az ipari környezetben is. Robert Soloff laborvezető idejében a Branson Instruments vállalatnál azzal foglalkoztak, hogy mủanyag fóliákat hegesztettek össze zsákokká. Egy nap véletlenül a műanyagszalag-adagolóhoz érintette a hegesztő szondát, és ezek kötést létesítettek. Ekkor eszmélt rá, hogy az ultrahang képes átlépni és terjedni a szilárd anyagokban is, és ezáltal képes összehegeszteni a különböző anyagokat. 1969-ben jelent meg az első, műanyagból készített autó, amelyet ennek az eljárásnak a felhasználásával hozott létre a Robert Soloff által alapított Sonics\&Materials nevü vállalat. Igaz, a kisautó nem aratott nagy sikert, de a technológia megtette az első lépést a naggyá váláshoz, ekkor kezdték el ugyanis felfedezni a benne rejlő lehetőségeket. Bár ez a termék nem aratott osztatlan sikert, a gyár sikeresen üzemel a mai napig, és azóta is foglalkoznak az ultrahangos hegesztéssel is.
Az ultrahangos hegesztés során a felületeket kis nyomásnak tesszük ki, mely közben az ultrahang által keltett rezgőmozgás a hegesztett felületek érdességi kiemelkedéseit és az oxidrétegeket roncsolja, és ezáltal a fémes felületeket egymásba dörzsöli, létrehozva a kötést. A művelet hatalmas előnye, hogy nem kell hőt közölni kívülről a munkadarabbal, így a hősokkból keletkező deformációk elkerülhetők. Kiválóan alkalmas műanyagok, acélok és egyéb fémek hegesztésére, eltekintve a kivételektől, például túl kemény anyagoknál gyorsan felléphet a kifáradás okozta repedés, ellenben a jól alakítható és nagy csillapítási tényezőjű anyagok jól hegeszthetők [4].

További előnye az eljárásnak, hogy a környezetet nagyon minimális szinten terheli, semmilyen káros hulladék a technológiai folyamat során nem termelődik.

\section{Ultrahangos hegesztés}

Ez a hegesztési mód igen érdekes, hiszen elektromos áramból állít elő rezgéseket, mely rezgések a hegesztőfejen (szonotródán) keresztül rezgetik meg a megmunkálandó darabot. Ennek a hatásnak, valamint az összeszorító erőnek a hatására következik be maga a hegesztés. A folyamat során nincs nagy hőhatásövezet, illetve mind ponthegesztésként, mind vonalhegesztésként lehet alkalmazni. A folyamat időigénye kicsi, például ponthegesztés esetében 1-2 másodperc. Ezzel az eljárással könnyen lehet hegesztést végezni különböző anyagok között, ugyanakkor sajnos csak nagy alakíthatóságú, nemridegedő anyagokhoz alkalmazható. Fontos, hogy a munkadarab vastagsága ne legyen nagy, ugyanis a hegesztés $0,5-1,5 \mathrm{~mm}$ közötti lemezvastagság esetén használható. Ezért a kísérleteket ezeket a paramétereket betartva valósítottuk meg [5].

A berendezés elektrostrikciós vagy magnetostrikciós elven működik (1. ábra).

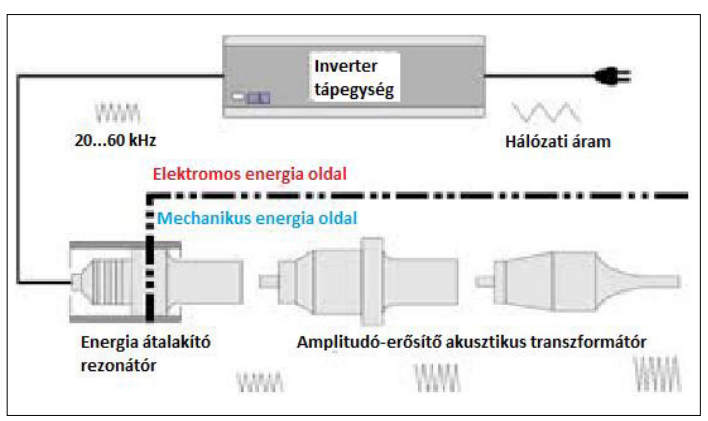

1. ábra. Az ultrahangos ponthegesztés sematikus ábrája [1] 
Az ultrahangos hegesztőgépeknek két nagy csoportja van: a vonal- és a ponthegesztők. Ezek elve szinte teljesen megegyezik. A legfőbb különbség, hogy a vonalhegesztő esetében a hangkeltő és az átvitelt biztosító tagok mind forgathatók, illetve a szonotróda és az ülők is. Az ultrahangos ponthegesztőgép külsőleg az ellenállás-hegesztő géphez hasonlít (2. ábra). A megmunkálandó darabok a szonotróda és gép üllője között helyezkednek el. A szorító terhelést hidraulikus vagy pneumatikus gépezet hozza létre.

\section{Az alkalmazott anyagok és a kísérletek}

Ausztenites korrózióálló acél és réz összehegesztése az eltérő fizikai, kémiai és mechanikai tulajdonságaik miatt nem egyszerű feladat. Előkísérletek során már elvégeztük a réz-réz és az ausztenites korrózióálló acél ultrahangos hegesztési paramétereinek optimalizálását.

A kísérleteink során két anyagot használtunk: egy rozsdamentes acéllemezt, illetve egy 99,5\%-os tisztaságú rézlemezt, a 3. ábrán jelölt méretekkel.

Az alkalmazott, X5CrNi8-10 (1.4301) minőségű rozsdamentes acélra, gyorshütéssel lágyított ál-

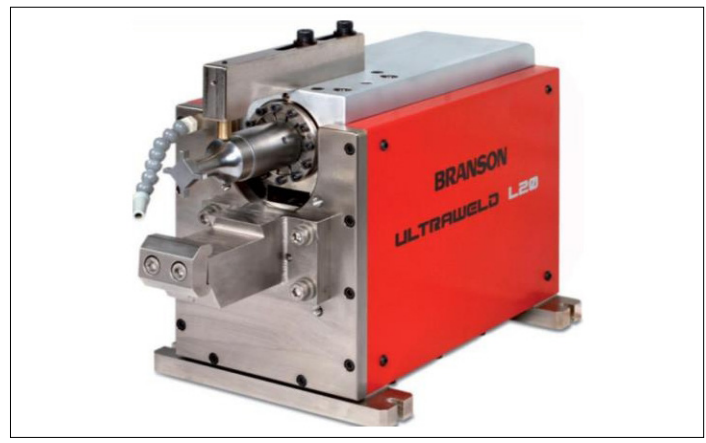

2. ábra. Az alkalmazott ponthegesztő gép

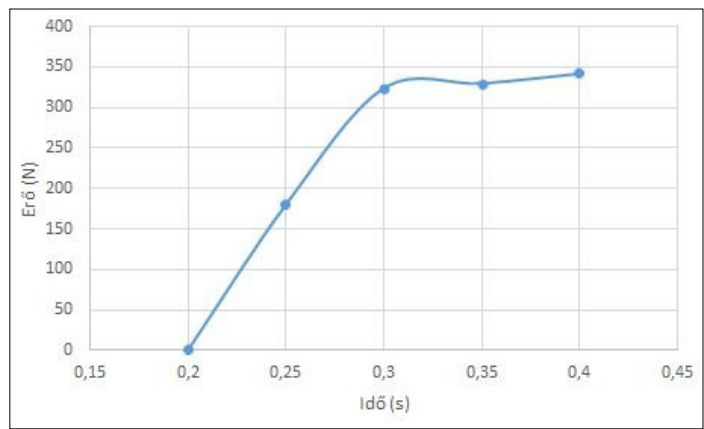

4. ábra. A maximális szakítóerő a hegesztési idő függvényében állandó amplitúdó és hegesztési sajtoló terhelés mellett (paraméterek: amplitúdó = $50 \mu \mathrm{m}$; Elö- és föterhelés: 0,345 MPa) lapotban jellemző mechanikai tulajdonságok: egyezményes folyáshatára $\mathrm{R}_{\mathrm{p} 0,2}=190 \mathrm{MPa}$, szakítószilárdsága $\mathrm{R}_{\mathrm{m}}=500-700 \mathrm{MPa}$, villamos vezetőképessége $0,73 \mathrm{~m} /\left(\Omega \cdot \mathrm{mm}^{2}\right)$.

Az alkalmazott CW024A (Cu-DHP 2.0090) rézlemezre jellemző, hogy jól alakítható, kiváló villamos vezetőképességű [ $\left.56-58 \mathrm{~m} /\left(\Omega \cdot \mathrm{mm}^{2}\right)\right]$ és jó korrózióállóságú, szakítószilárdsága $\mathrm{R}_{\mathrm{m}}=240 \mathrm{MPa}$, egyezményes folyáshatára $R_{p 0,2}=180 \mathrm{MPa}$, keménysége 65-95 HB.

A vizsgálataink során a szakirodalom tanulmányozása alapján egy egymásra épülő kísérletsorozatot folytattunk [6, 7]. Először a hegesztési idő függvényében kapott eredményeket elemeztük, majd az amplitúdó, végül a fő sajtoló terhelés szerint kapott eredményeket. A legnagyobb húzóerő-eredmények elérése után elvégeztünk egy korrekciós mérést, hogy a paraméteregyüttes mindegyik külön pontban felvett értéket adja végeredményben is. A mért maximális húzóerőt az amplitúdó és a hegesztési idő függvényében (4. és 5. ábra) mutatja.

Az elő- és főterhelés értékét a berendezés pneumatikus hengerében a hegesztés során fennálló

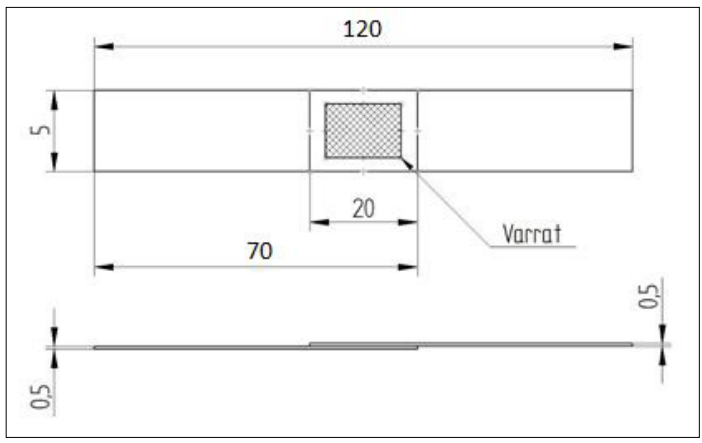

3. ábra. A hegesztett próbatest kialakítása

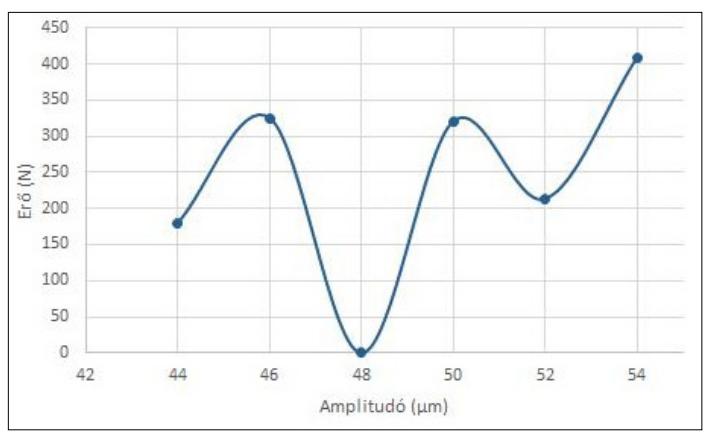

5. ábra. A maximális szakítóerő az amplitúdó függvényében (paraméterek: idő: 0,3 s; Elö- és föterhelés: 0,3 MPa) 
nyomás értéke szerint kell megadni (0,345 MPa).

A mérések 7\%-os szórást mutattak az egyes tesztek során, melyek az ultrahangos hegesztés esetében elfogadhatónak tekinthetőek.

Mivel az ausztenites acél hővezető képessége kicsi, hőkamerával láthatóvá válnak a hő-, illetve feszültséggyüjtő helyek, ahogyan ez megfigyelhető a következő, 6. ábrán is.

A réz és az ausztenites korrózióálló acél vegyes kötések ultrahangos hegesztési paramétereinek meghatározásához próbahegesztéseket végeztünk.

A vizsgálataink során azt állapítottuk meg, hogy a legjobb paraméteregyüttes a kötés kialakítására az alkalmazott acél és réz esetében az 1. táblázatban található paraméterek voltak.

1. táblázat. Az ultrahangos hegesztés legjobbnak talált paraméterei

\begin{tabular}{|l|c|}
\hline \multicolumn{1}{|c|}{ Paraméter } & Mennyiség \\
\hline $\begin{array}{l}\text { Elő- és főterhelés } \\
\text { (berendezés nyomásértéke) }\end{array}$ & $0,345 \mathrm{MPa}$ \\
\hline Idő & $0,3 \mathrm{~s}$ \\
\hline Amplitúdó & $50 \mu \mathrm{m}$ \\
\hline
\end{tabular}

\section{Következtetések}

A kísérletek eredményei alapján elmondhatjuk, hogy az ultrahangos hegesztéssel jó eredményekkel lehet egyesíteni a különböző olvadáspontú anyagokat. A vizsgált réz- és acéllemezek közti kötés megvalósítható, és a kötések szilárdsága is megfelelőnek tekinthető, mivel a nyíró-szakító vizsgálat során nem a varratban szakadtak el a kísérleti darabok.

$\mathrm{Az}$ alkalmazott Branson berendezéssel végzett kísérletek eredményei szerint az alkalmazott, X5CrNi8-10 (1.4301) minőségű rozsdamentes acél és a CW024A (Cu-DHP 2.0090) rézlemez hegesztése az optimális varratszilárdság eléréséhez javasolt paraméterek a következőek: hegesztési idő 0,3 s, amplitúdó $50 \mu \mathrm{m}, 0,345$ MPa elő- és fősajtoló terhelés mellett, melyet hidraulikus rendszer biztosít a hegesztés során.

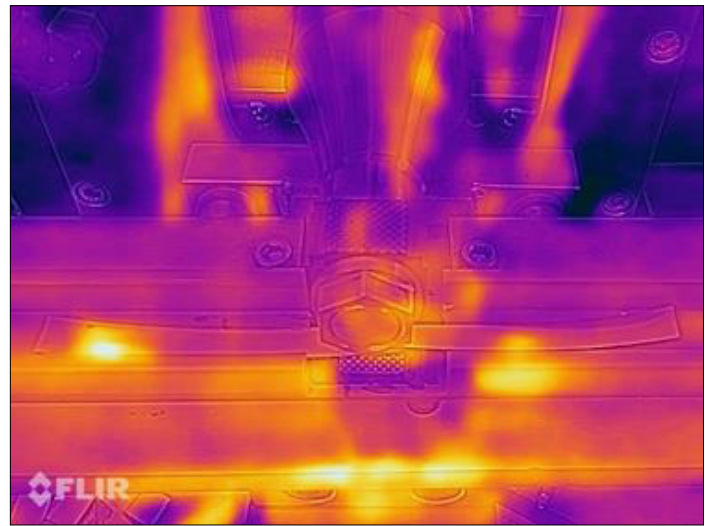

6. ábra. Ultrahangos ponthegesztés hőkamerás képe, hőmérsékleti színskálát nem tartalmaz, mert a hőkamera nem kalibrált

\section{Szakirodalmi hivatkozások}

[1] Bagyinszki Gy., Bitay E.: Hegesztéstechnika II. Berendezések és mérések. Müszaki Tudományos Füzetek 10., EME, Kolozsvár/Cluj, 2010. https://doi.org/10.36242/mtf-09

[2] Bagyinszki Gy., Bitay E.: Hegesztéstechnika I. Eljárások és gépesítés. Műszaki Tudományos Füzetek 9., EME Kolozsvár/Cluj, 2010. https://doi.org/10.36242/mtf-08

[3] Woo J.: A short History of the development of Ultrasound in Obstetrics and Gynecology. Pierre Curie. (letölte: 2019. 04. 15.)

http://www.ob-ultrasound.net/curie.html

[4] Wu X., Liu T., Cai W.: Microstructure, Welding Mechanism, and Failure of $\mathrm{Al} / \mathrm{Cu}$ Ultrasonic Welds. Journal of Manufacturing Processes, 20/1. (2015) 321-331.

https://doi.org/10.1016/j.jmapro.2015.06.002

[5] Astashev V. K., Babitsky V. I.: Ultrasonic Processes and Machines, Dynamics, Control and Applications. Springer-Verlag Berlin and Heidelberg, 2007, 33-45.

[6] Callister W. D., Rethwisch D. G.: Materials science and engineering an introduction, $8^{\text {th }}$ ed., John Wiley\&Sons, Inc. USA, 2000. 219-222.

[7] Chen K., Zhang Y.: Mechanical analysis of ultrasonic welding considering knurl pattern of sonotrode tip. Materials and Design, 87/5. (2015) 393-404. https://doi.org/10.1016/j.matdes.2015.08.042 